\title{
Effective healthcare teams require effective team members: defining teamwork competencies Sandra G Leggat*
}

\author{
Address: School of Public Health, La Trobe University, Victoria, 3086, Australia \\ Email: Sandra G Leggat* - s.leggat@latrobe.edu.au \\ * Corresponding author
}

Published: 7 February 2007

BMC Health Services Research 2007, 7:17 doi:10.1186/1472-6963-7-17
Received: 30 January 2006

Accepted: 7 February 2007

This article is available from: http://www.biomedcentral.com/1472-6963/7/17

(C) 2007 Leggat; licensee BioMed Central Ltd.

This is an Open Access article distributed under the terms of the Creative Commons Attribution License (http://creativecommons.org/licenses/by/2.0), which permits unrestricted use, distribution, and reproduction in any medium, provided the original work is properly cited.

\begin{abstract}
Background: Although effective teamwork has been consistently identified as a requirement for enhanced clinical outcomes in the provision of healthcare, there is limited knowledge of what makes health professionals effective team members, and even less information on how to develop skills for teamwork. This study identified critical teamwork competencies for health service managers.

Methods: Members of a state branch of the professional association of Australian health service managers participated in a teamwork survey.

Results: The $37 \%$ response rate enabled identification of a management teamwork competency set comprising leadership, knowledge of organizational goals and strategies and organizational commitment, respect for others, commitment to working collaboratively and to achieving a quality outcome.

Conclusion: Although not part of the research question the data suggested that the competencies for effective teamwork are perceived to be different for management and clinical teams, and there are differences in the perceptions of effective teamwork competencies between male and female health service managers. This study adds to the growing evidence that the focus on individual skill development and individual accountability and achievement that results from existing models of health professional training, and which is continually reinforced by human resource management practices within healthcare systems, is not consistent with the competencies required for effective teamwork.
\end{abstract}

\section{Background}

Teamwork is essential in the provision of healthcare. The division of labor among medical, nursing and allied health practitioners means that no single professional can deliver a complete episode of healthcare [1]. Yet there is little formal training in teamwork skill development in undergraduate or postgraduate health professional education programs - teamwork skills are largely learned 'on- the-job' [2]. In healthcare, where patient outcomes are dependent on effective interdisciplinary teamwork, there is need for better preparation of health professionals in teamwork.

Although many studies have identified teamwork as a requirement for high quality, safe patient care [3-7], within healthcare we have limited understanding of how 
individual health professionals contribute to effective teamwork. While there has been substantial study attempting to identify and define the requirements for effective healthcare teams, the predominant focus has been on improving existing teams [8-10]. There has been little research into the educational and training needs of healthcare professionals to enhance their participation in workplace teams; healthcare team members do not understand the personal competencies required for team success [11]. To assist in planning formal education programs this study aimed to identify the competencies held by healthcare professionals that were perceived by health service management colleagues to enhance teamwork. It has been suggested that "each team member's abilities, skills experience, attitudes, values, role perceptions and personality - all the things that make a person unique - determine what they are willing and able to contribute, their level of motivation, methods of interaction with other group members and degree of acceptance of group norms and the organization's goals" [[12], p. 676]. This suggests the need to focus on individual characteristics that have been found to contribute to teamwork, as "pre-requisite characteristics of effective teamwork" [[13], p. 204].

Generally understood as the clusters of skills, abilities and knowledge needed for occupational tasks competencybased health professional education has had a long history and is stressed in the accreditation of healthcare management education programs world wide [14-17]. In addition, there is increasing evidence that management competencies are an important source of competitive advantage for organizations $[18,19]$. Given the long standing focus on competency requirements for health service managers this study aimed to identify the competencies that were seen by health service managers to be related to effective teamwork within a health service workplace.

\section{Methods \\ Study framework}

A systematic literature review was conducted using standard literature search techniques for the years 1995 to 2005. Online computer searches of relevant computerised bibliographic databases were completed, using the key words "team, teamwork, inter-professional collaboration, multidisciplinary, competency and communities of practice". These computer searches were supplemented by exploration of documented teamwork competencies used for human resources management and management education purposes.

The research tends to be focused on improving team performance but few studies were identified with either randomised or control methods that enabled generalisation.
In addition studies tended to rely on subjective measures of team performance [20]. This is confounded by the finding that team members tend to be overly positive in their assessment of the performance of their group; yet this positive performance assessment is not generally supported by objective performance measures [21]. There were no sound empirical studies that confirmed the teamwork competencies related to successful teamwork performance, in general, or specifically related to health care. Therefore to develop the competency framework to be tested in this study a large number of experimental and non-experimental papers were reviewed with the intent of building a model that was comprehensive in outlining potential teamwork competencies as it was not possible to develop a model that was empirically supported.

Management competencies, the basis for healthcare management education, are generally considered to comprise skills, knowledge, traits (including attitudes) and motives (including values)[22,23], and therefore these four categories formed the basis for the model. Through the detailed literature review 18 skills, nine knowledge areas, 18 traits and 15 motives were identified as having relevance for effective teamwork (see Figure 1).

\section{Survey}

Survey methodology was used to ascertain the competencies perceived by health service managers to contribute to effective team participation in healthcare. The survey respondents were requested to identify the top quartile of each of the skills (5 out of 18), knowledge (3 out of 9), traits (5 out of 18) and motives ( 4 out of 15) from the lists in Figure 1 that they perceived to be most associated with the effective performance of a member of a management/ administrative or clinical care team in which they participated. The ranking approach was used as it has been shown to result in higher quality data than ratings [24]. Instead of ranking the entire list, the respondents were requested to identify only the top quartile to limit the primacy effect often found with ranking studies [24]. The reliability analysis provided Cronbach alpha of over 0.8 .

Based on the nature of health care, where clinical care teams are the main work teams responsible for producing healthcare services, and management teams are responsible for the organizational work through coordination and direction setting [25], the respondents were asked to focus their responses to either a management or a clinical team in which they had participated. The respondents were asked to only consider ongoing teams; project and other teams with one-time outputs were not included. Ethics approval was granted from the La Trobe University Ethics Committee. Data analysis comprised descriptive statistics and univariate chi-square using SPSS. 


\begin{tabular}{|c|c|c|c|}
\hline $\begin{array}{l}\text { SKILLS: } \\
\text { Ability to influence [39, } \\
79,80] \\
\text { Analysis of data [54] } \\
\text { Conflict management } \\
{[54,57,58,60,66]} \\
\text { Decision making [57] } \\
\text { Leadership [54, 57, 58, } \\
75] \\
\text { Listening [15, 25, 39, 58, } \\
71] \\
\text { Meeting management [54, } \\
57,58] \\
\text { Monitor \& evaluate [81] } \\
\text { Motivation of others [60, } \\
65] \\
\text { Negotiation [62] } \\
\text { Peer counselling [58] } \\
\text { Performance } \\
\text { management [11, 54, 58] } \\
\text { Planning [53, 58] } \\
\text { Provision of feedback [11, } \\
59] \\
\text { Self-management [81] } \\
\text { Time management [59] } \\
\text { Verbal communication } \\
\text { [15, 54, 58] } \\
\text { Written communication } \\
\text { [15, 54, 58] }\end{array}$ & $\begin{array}{l}\text { KNOWLEDGE: } \\
\text { Case/care management } \\
\text { [80] } \\
\text { Clinical content [63] } \\
\text { Knowledge of } \\
\text { management [63] } \\
\text { Organizational goals \& } \\
\text { strategies [34] } \\
\text { Organizational politics } \\
\text { [59] } \\
\text { Organizational roles of } \\
\text { other team members [10, } \\
\text { 58, 61, 73, 74, 76] } \\
\text { Self-awareness [13] } \\
\text { Team process \& } \\
\text { development [54, 62, 64, } \\
\text { 69] } \\
\text { Understanding KPIs [54] }\end{array}$ & $\begin{array}{l}\text { TRAITS: } \\
\text { Age [25, 52, 64] } \\
\text { Appearance [25, 52, 64] } \\
\text { Assertive behaviour [59] } \\
\text { Cooperative attitude [65] } \\
\text { Courage to disagree [5, } \\
33,70] \\
\text { Self-directed learning [13, } \\
76] \\
\text { Encourages others [57, } \\
60,65] \\
\text { Facilitates participation [5, } \\
10,33,34,75] \\
\text { Interpersonal } \\
\text { relationships [62, 72, 78] } \\
\text { Judgement [68] } \\
\text { Personality [53, 79] } \\
\text { Positive attitude [14, 65] } \\
\text { Reflective practice [81] } \\
\text { Respect for others [39, } \\
73,82] \\
\text { Self-confidence [63] } \\
\text { Sense of humour [57] } \\
\text { Teamwork experience } \\
\text { [54] } \\
\text { Tolerant of stress [15, 80] }\end{array}$ & $\begin{array}{l}\text { MOTIVES: } \\
\text { Commits to working } \\
\text { collaboratively }[11,14,56, \\
58,73,80] \\
\text { Commits to interdisciplinary } \\
\text { processes }[57,61,73] \\
\text { Commits to organization } \\
{[15,55,76]} \\
\text { Commits to profession [25] } \\
\text { Commits to quality outcome } \\
{[34,63]} \\
\text { Ethical practice [67] } \\
\text { Having fun }[12] \\
\text { Need to win [77] } \\
\text { Consumer focus [15, 55, 57, } \\
63] \\
\text { Social justice [63] } \\
\text { Strive for recognition }[79] \\
\text { Strive for high performance } \\
{[54,60,77,79]} \\
\text { Support for team decisions } \\
{[62]} \\
\text { Support of team goals }[62] \\
\text { Task completion }[53,71,79]\end{array}$ \\
\hline
\end{tabular}

\section{Figure I}

Possible skills, knowledge, traits and motives influencing teamwork. A figure illustrating the findings of the literature review used to develop the potential competencies explored in this paper. The reference list for the competencies in Figure I appear in the main reference list [5, 10-15, 25, 33, 34, 39, 52-82] (i.e. [5] [10] [1 I] [12] [13] [14] [15] [25] [33] [34] [39] [52] [53] [54] [55] [56] [57] [58] [59] [60] [6I] [62] [63] [64] [65] [66] [67] [68] [69] [70] [7I] [72] [73] [74] [75] [76] [77] [78] [79] [80] [8I] [82])

\section{Study population}

Pre-testing was completed by a small sample of five individuals drawn from the target population to identify the time requirements to complete the questionnaire and ensure the clarity of the questions. The questionnaire was then distributed by email to the 680 members of the Victorian State Branch of the Australian College of Health Service Executives (College). Membership of this College requires current study in or completion of an accredited health service management course and/or employment as a senior health service manager in a recognized position. Based on error messages in transmission and emails returned to source it was estimated that around 600 members received the emailed questionnaire. The completed surveys were emailed to an administrative mailbox where all identifying information was removed before the surveys were provided for data entry and analysis. Eleven completed questionnaires were returned by post.

\section{Results}

Following emailed reminders, 224 completed surveys were returned for a $37 \%$ response rate. The demographics of the respondents (Table 1) were representative of the sampled population, with $132(60 \%)$ female and 90 (40\%) male. Two surveys were returned without the demographic information completed. The majority of the respondents were senior managers $(n=11451.4 \%)$, with 52 Chief Executive Officers (CEOs) (23.4\%), 33 middle managers (14.9\%) and $23(10.4 \%)$ describing themselves as 'other'. The majority $(60.8 \%)$ of the respondents reported an age range of 40 to 59 years.

As expected from this sample of members of a professional management organization, the majority ( $\mathrm{n}=198$ $88 \%$ ) choose a management team as the focus for the questionnaire. It was surprising that any of the respondents choose a clinical team, but there were 26 (12\%) com- 
Table I: Reported age range, gender and position

\begin{tabular}{lcccccccccc}
\hline Position & & CEO & \multicolumn{2}{c}{ Senior Manager } & \multicolumn{2}{c}{ Middle Manager } & & Other & Total \\
\hline Age/Sex & F & $M$ & $F$ & $M$ & $F$ & M & F & M & $\#$ & $\%$ \\
\hline $20-39$ yrs & 4 & 9 & 28 & 14 & 7 & 3 & 8 & 4 & 77 & 34.7 \\
$40-59$ yrs & 14 & 25 & 46 & 16 & 14 & 9 & 5 & 6 & 135 & 60.8 \\
$60+$ yrs & 0 & 0 & 6 & 4 & 0 & 0 & 0 & 0 & 10 & 4.5 \\
Total & 18 & 34 & 80 & 34 & 21 & 12 & 13 & 10 & 222 & 100 \\
\hline
\end{tabular}

pleted questionnaires that focused on a clinical care team. Only four males completed their questionnaire based on a clinical team, perhaps indicative of the greater proportion of male respondents in CEO and senior management positions. The sample size of 26 is small for the clinical team respondents and therefore the clinical team results cannot be considered to have the same validity as the management team results and are not reported. However the fact that the respondents identified different competencies for the clinical and management teams lends some support for previous study that has shown that different team types will have different determinants of effectiveness [25].

The respondents were asked to consider team success as achievement of team goals and team member satisfaction. The respondents were requested to identify from the list in Figure 1 the skills, knowledge, traits and motives that the most effective team members demonstrated and that they had observed to enhance team performance. Respondents were also given the opportunity to add to the lists. There were three additions: project management was cited by one respondent as an important skill, and tenacity and tolerance of ambiguity were added as relevant traits.

While the primary purpose of this study was to identify a set of competencies, post hoc analysis of the data suggested differences in responses on two variables of gender and position within the organization, confirmed by chi square analysis. These post hoc analyses were chosen as previous study has found differences between the approaches of male and female managers [26,27] and the requirement for different competencies among different levels of health service managers $[17,28,29]$.

The purpose of this study was to identify the competencies that were seen by health service managers to be related to effective teamwork within a health service workplace. To identify the competencies the data analysis focused on the characteristics that were identified by more than $50 \%$ of the respondents. This approach is consistent with previous teamwork study by McDonough who found that in each category one variable was mentioned much more frequently than the others by the study respondents [30].

Table 2: Skill frequencies

\begin{tabular}{lrr}
\hline SKILLS & $\#$ & $\%$ \\
\hline Ability to influence & 89 & 44.9 \\
Analysis of data & 90 & 45.5 \\
Conflict management & 17 & 8.6 \\
Decision making & 82 & 41.4 \\
Leadership & 116 & 58.6 \\
Listening & 82 & 4.4 \\
Meeting management & 25 & 12.6 \\
Monitoring \& evaluation & 37 & \\
Motivation of others & 55 & \\
Negotiation & 48 & \\
Peer counseling & 12 & \\
Performance mgmt & 15 & \\
Planning & 76.7 \\
Provision of feedback & 76 & \\
Self-management & 37 & 3.1 \\
Time management & 56 & 18.4 \\
Verbal communication & 20 & 28.3 \\
Written communication & 76 & 3.1 \\
\hline
\end{tabular}

The percentages are based on the number of respondents. 
Table 3: Knowledge frequencies

\begin{tabular}{lrr}
\hline KNOWLEDGE & $\#$ & $\%$ \\
\hline Case/care management & 31 & 16 \\
Clinical knowledge & 52 & 26.8 \\
Management knowledge & 59 & 30.4 \\
Org goals \& strategies & 114 & 58.8 \\
Organizational politics & 71 & 36.6 \\
Roles of team members & 41 & 21.2 \\
Self-awareness & 83 & 42.8 \\
Team development & 63 & 32.5 \\
Understanding of KPls & 60 & 30.9
\end{tabular}

The percentages are based on the number of respondents.

Those competencies that were identified by more than $50 \%$ of the respondents were likely to represent the competencies thought most important by the respondent sample.

\section{Skills}

The ability to perform an activity, a skill, can be the result of natural talent or acquired through education or training. As shown in Table 2 only one skill, leadership, was identified as important by more than $50 \%$ of the respondents. The differences in responses by sex $(n=198)$ were examined and only two skill areas were found to be related to the sex of the respondent. The male respondents were significantly more likely than the female respondents to identify ability to influence as an important skill ( $\chi^{2}$ $=7.4901 \mathrm{df} p=0.006)$, while the female respondents were significantly more likely to identify negotiation as an important skill $\left(\chi^{2}=5.8781 \mathrm{df} p=0.015\right)$. However when the analysis was completed by position the female CEO respondents were significantly less likely than the female respondents in other positions to identify negotiation as an important skill $\left(\chi^{2}=8.0063 \mathrm{df} p=0.046\right)$.

\section{Knowledge}

As shown in Table 3 the knowledge area with over 50\% response was knowledge of organizational goals and strategies. Female respondents were significantly more likely than male respondents to identify self-awareness of strengths and weaknesses as important knowledge $\left(\chi^{2}=\right.$ $15.1721 \mathrm{df} \mathrm{p}=0.000)$.

\section{Traits}

Individual characteristics or traits may be highly visible demographic characteristics such as age or appearance, or may be less apparent, such as attitudes. In regards to traits the management team respondents identified respect for others as the most important trait (Table 4).
The female respondents were significantly more likely than the male respondents to consider positive attitude as an important trait $\left(\chi^{2}=7.1541 \mathrm{df} p=0.007\right)$. The male senior and middle management respondents were significantly more likely to include self-directed learning $\left(\chi^{2}=\right.$ $22.7213 \mathrm{df} \mathrm{p}=0.000$ ) than the CEO and other male respondents. The male CEO and female senior manager respondents were less likely to include respect for others (male: $\chi^{2}=13.8103 \mathrm{df} \mathrm{p}=0.003$, female: $\chi^{2}=11.5923 \mathrm{df}$ $\mathrm{p}=0.009$ ) as a trait as compared to the respondents from the other male and female management categories.

\section{Motives}

This group included perceived intrinsic values and personal motives. The most important motives seen to contribute to the success of the team were commitment to working collaboratively, commitment to the organization and commitment to a quality outcome (Table 5).

There were no significant motive differences among male and female respondents. The CEO respondents for both males and females were significantly more likely to indicate commitment to organization (male: $\chi^{2}=13.5533 \mathrm{df} \mathrm{p}=$ 0.004 female: $\chi^{2}=13.0313 \mathrm{df} \mathrm{p}=0.005$ ) and significantly less likely to indicate task completion (male: $\chi^{2}=20.4263$ df $\mathrm{p}=0.000$ female: $\chi^{2}=11.1063 \mathrm{df} \mathrm{p}=0.011$ ) as key motives.

\section{Discussion}

The respondent sample reflected the population of health service managers in the State of Victoria, Australia. The survey respondents were requested to identify the competencies that they had seen in other team members which enhanced teamwork. We know that individuals often identify characteristics in others that are most like their own characteristics [31] which suggests that there is a chance the respondents reported characteristics most like the ones they themselves possessed and that were not necessarily related to effective teamwork. This risk was mini- 
Table 4: Trait frequencies

\begin{tabular}{lrr}
\hline TRAITS & $\#$ & $\%$ \\
\hline Age & 6 & 3 \\
Appearance & 2 & 1 \\
Assertive behaviour & 28 & 94.1 \\
Cooperative attitude & 90 & 47.5 \\
Courage to disagree & 95.5 \\
Self-directed learning & 32 & 16.2 \\
Encourages others & 53 & 26.8 \\
Facilitates participation & 85 & 42.9 \\
Interpersonal relations & 54 & 27.3 \\
Judgment & 61 & 30.8 \\
Personality & 67 & 13.6 \\
Positive attitude & 27 & 46.5 \\
Reflective practice & 92 & 19.2 \\
Respect for others & 38 & 56.6 \\
Self-confidence & 112 & 19.7 \\
Sense of humour & 39 & 40.9 \\
Teamwork experience & 81 & 20.7 \\
Tolerant of stress & 41 & \\
\hline
\end{tabular}

The percentages are based on the number of respondents.

mized by the questionnaire design that asked respondents to focus on an identified team, and an individual other then themselves who they perceived as having a positive impact on the team, and reporting on what they had observed. Another limitation is that the survey forced the respondents to identify their priorities within each of the skills, knowledge, traits and motives categories; while a set of competencies from all of these areas was identified, further study is required to rank the importance among the identified skills, knowledge, traits and motives.

\section{Management and clinical teams may require different competencies}

While the under-representation of clinical care teams in the sample made it difficult to test if the observed differences in the reported competencies between the management and clinical teams were statistically significant, the fact that a sample of health service managers distinguished between competencies for clinical and management teams is an important finding and needs further study. Previous teamwork research has confirmed that the type of team influences the factors related to effectiveness $[25,32]$ and this study suggested that within healthcare settings there are perceived differences in the competencies important for management and clinical teams.

\section{Management team competencies}

The management team competencies were strongly consistent with previous studies on teamwork performance. Three motives received the highest ranking of all the skills, knowledge, traits and motives; commitment to working col- laboratively (64.1\%), commitment to a quality outcome $(69.2 \%)$ and commitment to organization (64.6\%). Although not unequivocally supported through controlled experimental design, cross-sectional and case studies have suggested that teams with a climate of psychological safety $[5,33]$ that encourages high levels of participation [34] toward clear goals $[35,36]$ that enable high performance and quality expectations $[34,37,38]$ demonstrate better team performance $[33,39]$. The respondents in this study consistently identified three motives that reflected these previous findings.

This study approached the issue of team performance from a different perspective than previous studies. Instead of team level analysis we focused on the perceptions of health care managers of individual characteristics that contributed most to team success, and yet the results still supported previous study. From the perspective of these respondent managers, individuals participating in management teams in health care organizations were considered to have the greatest impact on team performance when they demonstrated commitment to working collaboratively, commitment to the organization and commitment to a quality outcome. Of all of the skills, knowledge, traits and motives that were provided, the fact that over $60 \%$ of the management team respondents indicated the importance of these three motives lends strong support for team members who:

- demonstrate their commitment to the organization by communicating organizational goals and objectives and 
Table 5: Motive frequencies

\begin{tabular}{lrr}
\hline MOTIVES & $\#$ & $\%$ \\
\hline Work collaboratively & 127 & 64.1 \\
Interdisciplinary & 28 & 14.1 \\
Commit to organization & 128 & 64.6 \\
Commitment to profession & 35 & 17.7 \\
Quality outcome & 137 & 69.2 \\
Ethical practice & 57 & 28.8 \\
Having fun & 39 & 19.7 \\
Need to win & 10 & 5.1 \\
Consumer focus & 98 & 49.5 \\
Social justice & 38 & 19.2 \\
Strive for recognition & 8.0 \\
High performance & 83 & 41.9 \\
Support team decisions & 83 & 31.3 \\
Support of team goals & 62 & 24.7 \\
Task completion & 49 & 36.9 \\
\hline
\end{tabular}

The percentages are based on the number of respondents.

assisting their team colleagues to translate the needs of the organization into performance outcomes for the team, and

- demonstrate their commitment to collaboration and quality by facilitating the needed psychological safety among team members that enables them to discuss and learn from mistakes and to challenge their team colleagues when it is required for a quality outcome.

It is clear that more methodologically and statistically rigorous investigation is required to better confirm the relationships between the competencies identified in this study and the performance of teams in health sector organizations. While progressive human resource management promotes participation, training and teamwork consistent with the identified management competencies, healthcare organizations do not always provide best practice HRM [40-42], and the people side of management has often been ignored in the pursuit of health reform $[43,44]$. In addition the traditional training and socialisation of health professionals tends to emphasise individual skills, accountability and achievement [45] and the healthcare system continues to foster individual [46] and discipline-specific rewards, supervision and education which consistently leads to difficulties with collaboration across professions, and reliance on hierarchy to manage coordination needs and mediate conflict [42]. The strong support for leadership skills among management team members in this study holds up the notion that within healthcare, leadership that rests at the top of an authority hierarchy needs to be refocused to develop leaders throughout the organization [47]. There needs to be a radical shift in HRM practice [40] in health care to train, performance manage and reward practices that result in clinical and management leaders through the organiza- tion - leaders that can foster the organizational commitment and psychological safety that is likely to improve teamwork outcomes.

In healthcare, employee relationships and behaviours are often influenced by the highly professional nature of the workforce, where there is often stronger alliance to the profession than to the organization. Many managers are professionally trained clinicians [48], and they often continue clinical practice even when they have assumed a management role. The findings of this study reinforce previous research that has identified the need for management training of clinician leaders [49-51]. Although many of the competencies developed in clinical education and ongoing clinical practice are transferable to management, there are skill and knowledge deficits [51]. The transition from clinician to manager requires a substantial cognitive shift from a primary commitment to individual care to a community/organizational focus [28].

This study also highlighted differences in perceptions among male and female health service managers that may influence team behaviours and ultimately team effectiveness. The differences noted in the responses of the male and female managers appear consistent with previous study.

For example, male leaders have been found to be more transactional and derive their power from their position on the formal organizational structure [26]. In contrast, women tend to be more transformational and derive their power from personal characteristics. In this study the male respondents demonstrated this transactional nature, identifying ability to influence as a key teamwork skill, while the female respondents suggested negotiation, self-awareness of strengths and weaknesses and positive attitude 
were important. Studies have suggested that women managers in male-dominated industries employ more 'masculine' management characteristics [27], and we found similarities between the women in CEO positions and male respondents. For example, the female CEOs were less likely than the female respondents at other organizational levels to identify negotiation as an important teamwork skill. While more study of these differences and the impact on team performance is warranted, these results provide some support for the differences in styles of male and female managers.

Different levels of health service managers require different competencies. It has been suggested that front line and/or entry level positions rely on technical expertise, middle managers require greater skills in human resource management and the senior level roles need greater conceptual skills $[17,28]$. Often the senior roles are thought to focus more on managing output related organizational adaptation and change [29], while junior levels manage the technical operational aspects of the organization. The findings provided some support. The CEO respondents were more likely to stress commitment to the organization and less likely to indicate task completion. The senior and middle managers focused more on transactional skills, such as negotiation and these manager respondents also stressed self-directed learning to a greater extent.

\section{Conclusion}

This study has explored the individual teamwork competencies perceived by health service managers to contribute to effective teamwork in management teams. The findings are consistent with other studies and support the need for a greater focus on progressive human resource management within the healthcare sector, with a focused teamwork development approach. The management team competencies suggested team success when the members displayed a strong focus on the organization and the values, climate and culture underlying effective interpersonal and teamwork relationships. The findings of this study will be used to develop focused teamwork training initiatives for health service managers.

\section{Competing interests}

The author(s) declare that they have no competing interests.

\section{Acknowledgements}

The author would like to thank the Australian College of Health Service Executives for the International Travel Scholarship that enabled the completion of this study.

\section{References}

I. Sicotte C, Pineault R, Lambert J: Medical interdependence as a determinant of use of clinical resources. Health Services Research 1993, 28(5):599-609.
2. Wake-Dyster W: Designing teams that work. Australian Health Review 200I, 24(4):34.

3. West MA, Borrill C, Dawson JF, Scully J, Carter M, Anelay S, Patterson MG, Waring J: The link between the management of employees and patient mortality in acute hospitals. International Journal of Human Resource Management 2002, I3(8): I299-I310.

4. National Coalition on Health Care, Institute for Healthcare Improvement: Accelerating Change Today A.C.T. for America's Health. Robert Wood Johnson Foundation; 2002:I-40.

5. Edmondson A: Psychological safety and learning behavior in work teams. Administrative Science Quarterly 1999, 44(2):350-353.

6. Ferlie EB, Shortell SM: Improving the quality of health care in the United Kingdom and the United States: A framework for change. The Milbank Quarterly 200I, 79(2):28I-3I5.

7. Berwick DM: A user's manual for the IOM's 'Quality Chasm' report. Health Affairs 2002, 2 I (3):80.

8. Shortell SM, Marsteller JA, Lin M, Pearson ML, Wu SY, Mendel P, Cretin $S$, Rosen $M$ : The role of perceived team effectiveness in improving chronic illness care. Medical Care 2004, 42(II): 1040-1048.

9. Lemieux-Charles L, Murray M, Baker GR, Barnsley J, Tasa K, Ibrahim $S A$ : The effects of quality improvement practices on team effectiveness: a mediational model. Journal of Organizational Behavior 2002, 23:533-553.

10. ledema R, Meyerkort S, White L: Emergent modes of work and communities of practice. Health Services Management Research 2005, 18:13-24

II. Dubnicki C, Limburg WJ: How do healthcare teams measure up? The Healthcare Forum Journal I99I, 34(5): I0-II.

12. Cole K: Supervision. Frenchs Forest, NSW, Prentice Hall; 2001.

13. Mickan S, Rodger S: Characteristics of effective teams: a literature review. Australian Health Review 2000, 23(3):20I-208.

14. National Center for Healthcare Leadership: Health Leadership Competency Model, version 2.0. [http://www.nchl.org/ns/docu ments/documents.asp].

15. MacKinnon NJ, Chow C, Kennedy PL, Persaud DD, Metge CJ, Sketris I: Management competencies for Canadian health executives: views from the field. Healthcare Management Forum 2004.

16. Australian College of Health Service Executives: Accreditation Guide. North Ryde, NSW, Australian College of Health Service Executives,; 2002.

17. Robbins C], Bradley EH, Spicer M: Developing leadership in health care administration: a competency assessment tool. Journal of Healthcare Management 200I, 46(3): I 88-202.

18. Hansen GS, Wernerfelt B: The relative importance of economic and organizational factors. Strategic Management Journal 1989, 10:399-4II.

19. Lado AA, Boyd NG, Wright P: A competency-based model of sustainable competitive advantage: toward a conceptual integration. Journal of Management 1992, I 8(I):77-92.

20. Salas E Rozell, Drew, Mullen B, Driskell JE: The effect of team building on performance: an integration. Small Group Research 1999, 30(3):309-329.

21. Paulus PB: Groups, teams and creativity: the creative potential of idea generating groups. Applied Psychology: An International Review 2000, 49:237-262.

22. McClelland DC: Testing for competence rather than intelligence. American Psychologist 1973, 28(I): I- 14.

23. Spencer LM, Spencer SM: Competence at Work. New York, John Wiley and Sons; 1993.

24. Krosnick JA: Survey research. Annual Review of Psychology 1990, 50:537-567.

25. Cohen SG, Bailey DE: What makes teams work: group effectiveness research from the shop floor to the executive suite. Journal of Management 1997, 23(3):239.

26. Rosener JB: Ways women lead. Harvard Business Review 1990:119-125.

27. Gardiner M, Tiggemann M: Gender differences in leadership style, job stress and mental health in male and female dominated industries. Journal of Occupational and Organizational Psychology 1999, 72(3):30I-3I5.

28. Lawson JS, Rotem A, Bates PW: From Clinician to Manager: An Introduction to Hospital and Health Services Management. Sydney, McGraw-Hill Book Company; 1996.

29. Wallick WG, Stager KJ: Healthcare managers' roles, competencies and outputs in organisational performance improve- 
ment/practitioner response. Journal of Healthcare Management 200I, 47(6):390-402.

30. McDonough EFIII: Investigation of factors contributing to the success of cross-functional teams. Journal of Product Innovation Management 2000, 17:221-235.

3I. Williams KY, O'Reilly CA: Demography and diversity in organisations: a review of $\mathbf{4 0}$ years of research. In Research in Organizational Behavior Edited by: Staw BM, Cannings LL. Greenwich, C.T. , JAI Press; 1998.

32. Devine D, Clayton LD, Philips JL, Dunford BB, Melner SB: Teams in organizations. Prevalence, characteristics, and effectiveness. Small Group Research 1999, 30(6):678-7|I.

33. Edmondson AC, Bohmer R, Pisano GP: Disrupted routines: team learning and new technology implementation in hospitals. Administrative Science Quarterly 200I, 46(4):685-7I6.

34. Borrill C, Carletta J, Carter AJ, Dawson JF, Garrod S, Rees A, Richards A, Shapiro D, West M: The Effectiveness of Health Care Teams in the National Health Service. London, Aston University University of Glasgow University of Leeds; 2002.

35. Young G]: Managing organizational transformations: lessons from the Veterans Health Administration. California Management Review 2000, 43(I):66-83.

36. Weiner BJ, Shortell SM, Alexander J: Promoting clinical involvement in hospital quality improvement efforts: the effects of top management, board and physician leadership. Health Services Research 1997, 32(4):49I-5I0.

37. Knight $D$, Durham CC, Locke EA: The relationship of team goals, incentives, and efficacy to strategic risk, tactical implementation and performance. Academy of Management Journal 200I 44(2):326-338.

38. Sparks JR, Schenk JA: Explaining the effects of transformational leadership: an investigation of the effects of higher-order motives in multilevel marketing organizations. Journal of Organizational Behavior 200I, 22:849-869.

39. Yeatts DE, Seward RR: Reducing turnover and improving health care in nursing homes: the potential effects of selfmanaged work teams. The Gerontologist 2000, 40(3):358-363.

40. Leggat SG, Bartram T, Stanton P, Fraser B: Exploring the lack of progress in improving patient safety in Australian hospitals. In Working Paper Melbourne , La Trobe University; 2005.

41. Radnor Z, McGuire M: Performance management in the public sector: fact or fiction? International Journal of Productivity and Performance Management 2004, 53(3):245-260.

42. Leggat SG, Dwyer J: Improving hospital performance: culture change is not the answer. Healthcare Quarterly 2005, 8(2):60-66.

43. Stanton $P$, Bartram T, Harbridge R: HRM practices in the public health sector: lessons from Victoria, Australia. Journal of European Industry and Training 2004, 28(2/3/4):3 I0-328.

44. Saltman R, Figueras J: European Health Care Reform. Analysis of Current Strategies. . In WHO regional publications European series no 72 Edited by: Europe WHORO. Copenhagen: ; 1997.

45. Committee on Quality of Healthcare in America: Crossing the Quality Chasm. A New Health System for the 2 I st Century. Edited by: Medicine I. Washington, D.C. , National Academy Press; 2001 .

46. Farmer EA: Assessing the performance of doctors in teams and systems. Medical Education 2002, 36(10):942-948.

47. Shortell SM: Developing individual leaders is not enough. Journal of Health Services Research and Policy 2002, 7(4): 193-194.

48. Harris M, Maddern J, Pegg S: The Changing Roles and Careers of Australian and New Zealand Health Service Managers. Sydney, Australian College of Health Service Executives; 1998.

49. Boucher CJ: To be or not to be ...a manager: the career choices of health professionals. Australian Health Review 2005, 29(2):218-225.

50. Prideaux G: Making the transition from health professional to manager. Australian Health Review 1993, I 6(I):43-50.

5I. Pilling S, Slattery J: Management competencies: intrinsic or acquired? What competencies are required to move into speech pathology management and beyond? Australian Health Review 2004, 27(I):84-92.

52. Alexander J, Lichtenstein R, Jinnett K, D'Aunno TA, Ullman E: The effects of treatment team diversity and size on assessments of team functioning. Hospital \& Health Services Administration 1996, $4 I(I): 37-53$
53. Bales RF: Personality and Interpersonal Behavior. New York, Holt, Reinhart and Winston; 1970.

54. Castka P, Bamber CJ, Sharp JM: Benchmarking intangible assets: enhancing teamwork performance using self-assessment. Benchmarking 2004, I I (6):57I-583.

55. Castka P, Bamber CJ, Sharp JM, Belohoubek P: Factors affecting successful implementation of high performance teams. Team Performance Management 2001, 7/8:123-134.

56. Cheng MI, Dainty ARJ, Moore DR: Towards a multidimensional competency-based managerial performance framework. A hybrid approach. 20 2005, 5(380-96):

57. Cole KD, Waite MS, Nichols LO: Organizational structure, team process and future directions of interprofessional health care teams. Geronotology \& Geriatrics Education 2003, 24(2):35-49.

58. Drinka T: Applying learning from self-directed work teams in a business to curriculum development for interdisciplinary geriatric teams. Educational Gerontology 1996, 22(5):433-450.

59. Field R, West M: Teamwork in primary health care. 2. Perspectives from practices. Journal of Interprofessional Care 1995, 9(2): $123-130$

60. Forsyth DR: Group Dynamics 2nd Ed. Pacific Grove, Ca, Brooks/ Cole; 1990.

61. Gilbert JH, Bruce C, Fielding DW, Stanton SJ: Preparing students for interprofessional teamwork in health care. Journal of Interprofessional Care 2000, 14(3):223-235.

62. Government of Canada: . [http://www.managers-gestionnaires.gc.ca/ career development/competency profiles/teamwork e.shtml].

63. Guo KL, Anderson D: The new health care paradigm. Roles and competencies of leaders in the service line management approach. Leadership in Health Services 2006, 18(4):xii-xx.

64. Harris M, Harris RD, Johnstone LP: Working with health teams. In Managing Health Services Concepts and Practice Edited by: Harris MG. Marrickville, NSW , Elsevier; 2006.

65. HayGroup: Management Competencies. 2005

66. Jehn KA, Mannix EA: The dynamic nature of conflict: a longitudinal study of intragroup conflict and group performance. Academy of Management Journal 200I, 44(2):238-25I.

67. Katzenbach J, Smith D: The Wisdom of Teams. Creating the High-Performance Organisation. New York , McGraw-Hill; 1993.

68. Legge $D$, Stanton $P$, Smyth A: Learning management (and managing your own learning). In Managing Health Services Concepts and Practice Edited by: Harris M. Marrickville, NSW , Elsevier; 2006

69. Main CJ, Spanswick CC: Pain management: an interdisciplinary approach. Edinburgh, Churchill Livingston; 2000.

70. Mannion R, Davies HTO, Marshall MN: Cultural characteristics of "high" and "low" performing hospitals. Journal of Health Organization and Management 2005, 19(6):43|-439.

71. McGregor D: The Human Side of the Enterprise. New York, McGraw Hill; 1960.

72. Mealiea LW, Latham GP: Skills for Managerial Success. Chicago , Irwin; 1996.

73. Nelson EC, Batalden P, Huber TP, Mohr J], Godfrey MM, Headrick LA, Wasson JH: Microsystems: Part I Learning from high performing front-line clinical units. Journal on Quality Improvement 2002, 28(9):472-493.

74. Reeves S, Lewin S: Interprofessional collaboration in the hospital: strategies and meanings. Journal of Health Services Research \& Policy 2004, 9(4):2। 8-225.

75. Ross F, Rink E, Furne A: Integration or pragmatic coalition? an evaluation of nursing teams in primary care. Journal of Interprofessional Care 2000, I 4(3):259-267.

76. Russell J: The disciplines of self-managed work teams: mastery leads to self-management success. Quality Matters 1994, 7(I): I-2.

77. Smith EA: Communities of competence. The Journal of Workplace Learning 2005, I7(1/2):7-23.

78. Sparrowe RT, Liden RC, Wayne SJ, Kraimer ML: Social networks and the performance of individuals and groups. Academy of Management Journal 200I, 44(2):3I6-325.

79. Stewart GL, Fulmer IS, Barrick MR: An exploration of member roles as a multilevel linking mechanism for individual traits and team outcomes. Personnel Psychology 2005, 58:343-365.

80. Vinokur-Kaplan D: Treatment teams that work (and those that don't): an application of Hackman's group effectiveness 
model to interdisciplinary teams in psychiatric hospitals. Journal of Applied Behavioral Science 1995, 3 I (3):303.

81. Watson P: Innovative Teaching, Teamwork and Generic Skills in the University Environment. :I-9.

82. Wellins RS, Byham WC, Wilson JM: Empowered Teams. San Francisco, Jossey-Bass; 1991.

\section{Pre-publication history}

The pre-publication history for this paper can be accessed here:

http://www.biomedcentral.com/1472-6963/7/17/prepub

Publish with Biomed Central and every scientist can read your work free of charge

"BioMed Central will be the most significant development for disseminating the results of biomedical research in our lifetime. " Sir Paul Nurse, Cancer Research UK

Your research papers will be:

- available free of charge to the entire biomedical community

- peer reviewed and published immediately upon acceptance

- cited in PubMed and archived on PubMed Central

- yours - you keep the copyright

Submit your manuscript here:

http://www.biomedcentral.com/info/publishing_adv.asp 